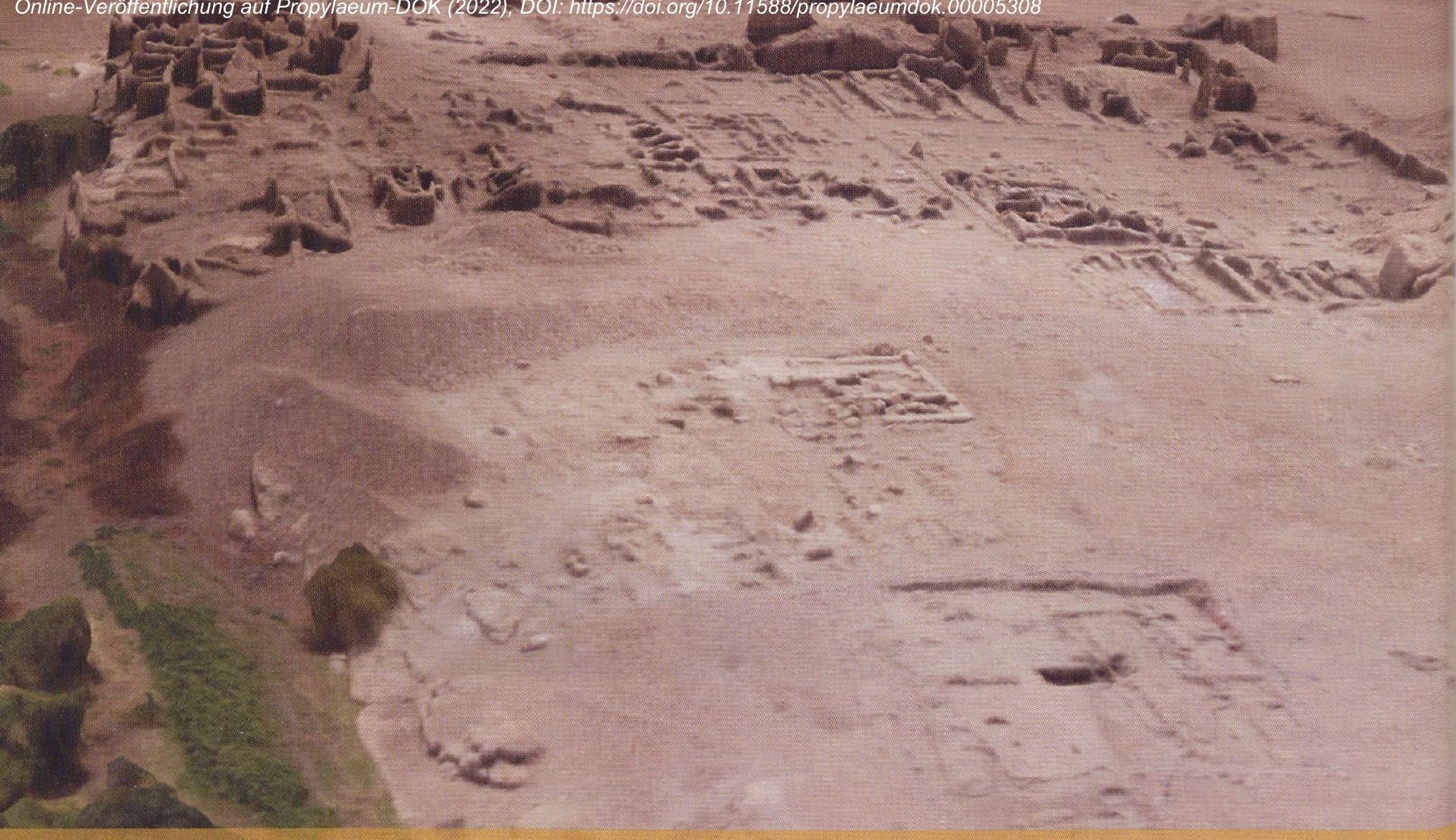

\title{
Crossing Borders
}

\section{Settlement Archaeology in Egypt and Sudan}

\section{Julia Budka}

\section{D model of the New Kingdom town of Sai. View from the north with SAV1 east and} potential landing place. Illustration by Martin Fera.

$A$ sone of the most important New Kingdom settlement sites in Upper Nubia, Sai Island represents the focal point of the European Research Council project AcrossBorders. The site can be understood as a prime example of the settlement policy of New Kingdom Egypt in Upper Nubia from the early Eighteenth Dynasty onwards.

Like the other major settlements in Kush, Sai Island (fig. 1) falls into the category of the so-called Nubian temple town-fortified towns built in the New Kingdom with an enclosure wall and a sandstone temple (Kemp 1972: 651-56; Morris 2005: 5). Temples as key elements of Egyptian towns are especially prominent in the Abri-Delgo Reach (Sesebi, Soleb, Tombos, Sai) and seem to be connected with the character of the area as a rich gold ore region (see Klemm and Klemm 2013: 9 and passim). A common feature for the specific urban layout of temple towns is the limited domestic space, with much of the room instead occupied by storage facilities and magazines, putting these sites into direct connection with the Egyptian administration of Kush (see Müller 2013). This partly explains why, until recently, most studies on these towns have focused on the temples and their economic aspects from a broad perspective, leaving aside the specific microhistories of the major sites. Essential questions like the character and density of occupation still remain open (Budka 2015c: 41). There is also no common understanding regarding the social interconnections and power hierarchies of Egyptians and Nubians in these towns, despite the fact that entanglement and appropriation are highly relevant phenomena and most scholars now believe in significant impact by indigenous elements (van Pelt 2013: 523-50; Spencer 2014b: 42-61).

Current excavations at the settlement sites in Upper Nubia have rich potential to answer some of these open questions, particularly the missions currently working at Amara West (Spencer 2014b), Sai (Budka 2015a, 2015b, 2015c), and Sesebi (Spence and Rose 2009; Spence, Rose et al. 2011). Complementary to 
the site just above the cliff (SAV1 NE, fig. 2). Despite a high degree of erosion and post-Pharaonic remains close to the surface, some mud-brick remains of the Eighteenth Dynasty were documented. The outline of the enclosure wall was found, allowing for the reconstruction of the eastern side. This discovery permits establishing the actual size of the town (fig. 3): $238 \mathrm{~m}$ north-south and $118 \mathrm{~m}$ east-west, for a total of 27,600 $\mathrm{m}^{2}$ (2.76 ha; Adenstedt 2016).

All in all, the geoarchaeological investigation by AcrossBorders supports the view that the New Kingdom town of Sai was founded, from a strategic perspective, at the perfect

Figure 2. Digital surface model (shaded relief) of the New Kingdom town of Sai with excavation areas. Illustration by Martin Fera.

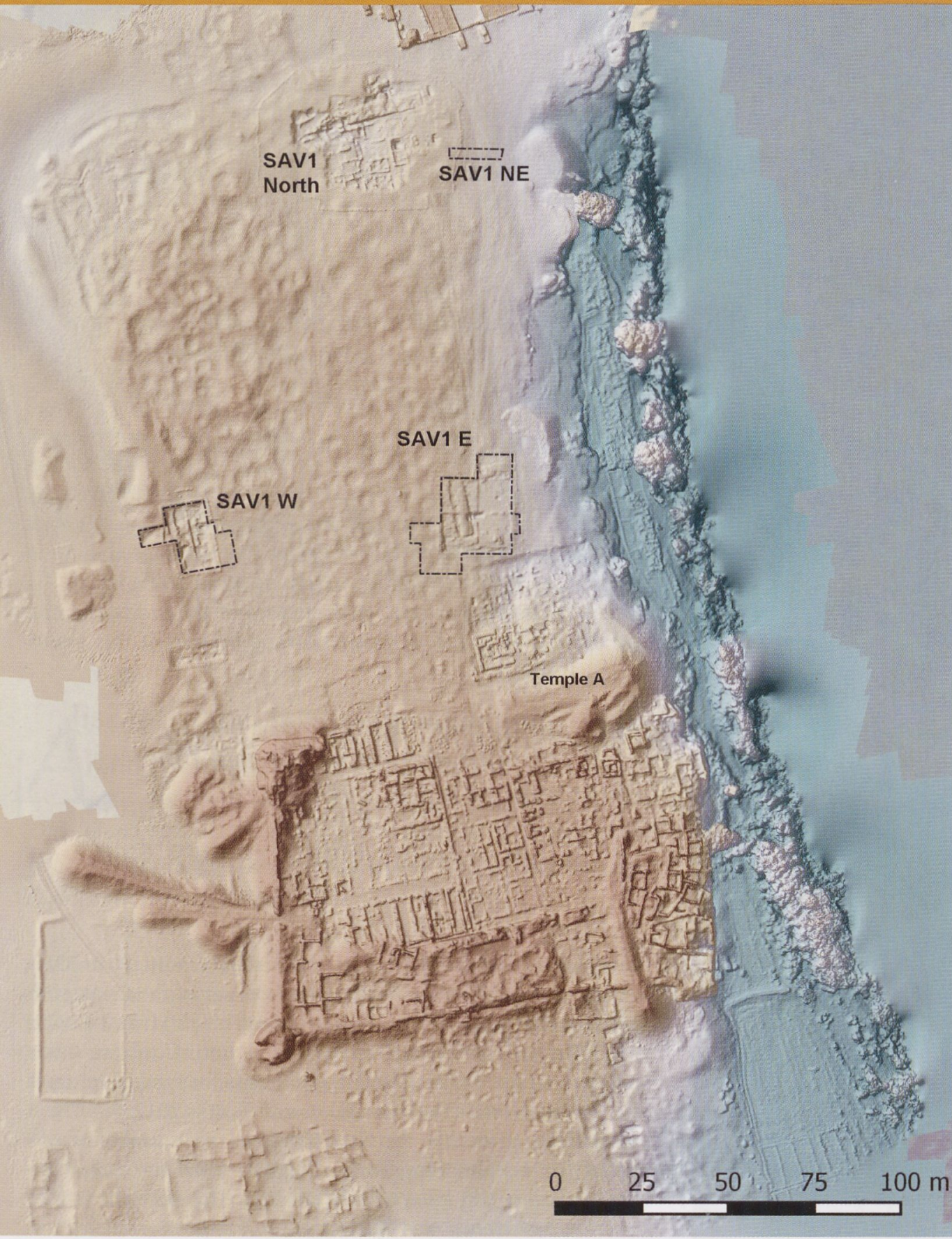

location on the island. This location was chosen mainly for control of river traffic, to facilitate the mooring and loading of ships, and for access to high-quality sandstone.

\section{The Layout and Planning of the New Kingdom Town}

Prior to AcrossBorders' work, two sectors had been excavated in the town area (fig. 3): the southern part (SAV1) below the Ottoman fortress-including the sandstone Temple A, founded by Thutmose III (Azim 1975) - and a sector along the northern enclosure wall (SAV1

North; Budka and Doyen 2013). Several distinct areas were identified in the southern sector, including (1) a palatial or residential quarter (SAF2); (2) a cluster of five houses making up the central domestic quarter $\mathrm{H}$; and (3) a western quarter (SAF5), consisting of several rectangular storage rooms and circular silos from an earlier phase. These quarters reflect the orthogonal planning of the town, organized along the north-south and eastwest axes. Parallels for such a layout can be found at other New Kingdom temple towns, especially at Buhen, Amara West and Sesebi (see Kemp 1972).

The architectural remains documented in sector SAV1 North (fig. 4), however, do not correspond to the general town planning visible in the southern sector. In the northern area, the structures adjacent to the enclosure wall are markedly different, but find close parallels in the new excavation area SAV1 West (fig. 5). The building units at SAV1 North include typical Egyptian tripartite houses, considerably smaller than the houses in SAV1, but similar to houses in Middle Kingdom Nubian fortresses (e.g., at Uronarti and Buhen). Other buildings units at SAV1 North do not find close parallels within Egyptian orthogonal settlements, contrasting markedly in both size and ground plan to the houses in SAV1. Thus, SAV1 North nicely illustrates that within the city of Sai there are several different 
sectors that contrast regarding their layout. As was recently illustrated by the neighboring site of Amara West, real developments within Egyptian towns may differ significantly from theoretical urban planning. It is therefore likely that a dissonance of houses from "standard types" like at SAV1 North were actually common and integral parts of very dynamic worlds, traceable in both Egypt and Nubia (Spencer 2014a: 201-2).

\section{Sector SAV1 East}

In 2013 the new excavation area SAV1 East was opened, 30 $50 \mathrm{~m}$ north of Temple $\mathrm{A}$ at the eastern edge of the town (fig. 6). The new squares were placed where the outline of an orthogonal building was visible on the geophysical survey map from 2011, aligned with Temple A, following the orientation of the buildings in the southern part of the town. On excavation, linear outlines filled with sand were revealed just below the surface, representing the negative outlines of the walls visible as anomalies on the magnetometer survey map. The Pharaonic building material once forming these walls had been almost completely removed during Medieval and Ottoman times. Excavations confirmed the orthogonal outline, alignment and date of a large mid-Eighteenth Dynasty structure, Building A (Budka 2015c: 43-45). Building A was constructed on terraces, with the lowest part in the east and much higher levels in the west. Despite the fragmentary state of preservation, the outline of this building is similar to SAF2, the governor's residence in the southern part of the town. Based on ceramics from the foundation trench, Building A belongs to the major remodelling of Sai during the reign of Thutmose III, making it contemporaneous with Temple A and the structures in the southern part of the town. However, earlier structures were noted in the southern part of SAV1 East, nicely corresponding to the remains excavated by Azim below the temple stratum. These storage installations probably belong to the earliest phase of Sai as an Egyptian landing place (Budka 2015b: 61-62).

One of the most important elements of SAV1 East is Feature 15, a subterranean room located in the central courtyard of Building A. More than two hundred remains of scarab seal impressions were documented from this feature, a large number of them with royal names
(Amenhotep I, Hatshepsut, and Thutmose III; Budka 2015c: 45). The large number of seal impressions indicates that Building A was used for the storage and distribution of products, possibly in close connection with the nearby temple. Thanks to a stratigraphic sequence, several phases of use can be reconstructed for Feature 15 (Budka 2015c: table 1), which mirror the building phases of Temple A and its surroundings. The earliest phase of Feature 15 might be directly related to the assumed landing place on Sai and is relevant for understanding the nature of the Egyptian presence in the first half of the Eighteenth Dynasty (see below). The latest phase of use illustrates close relations between

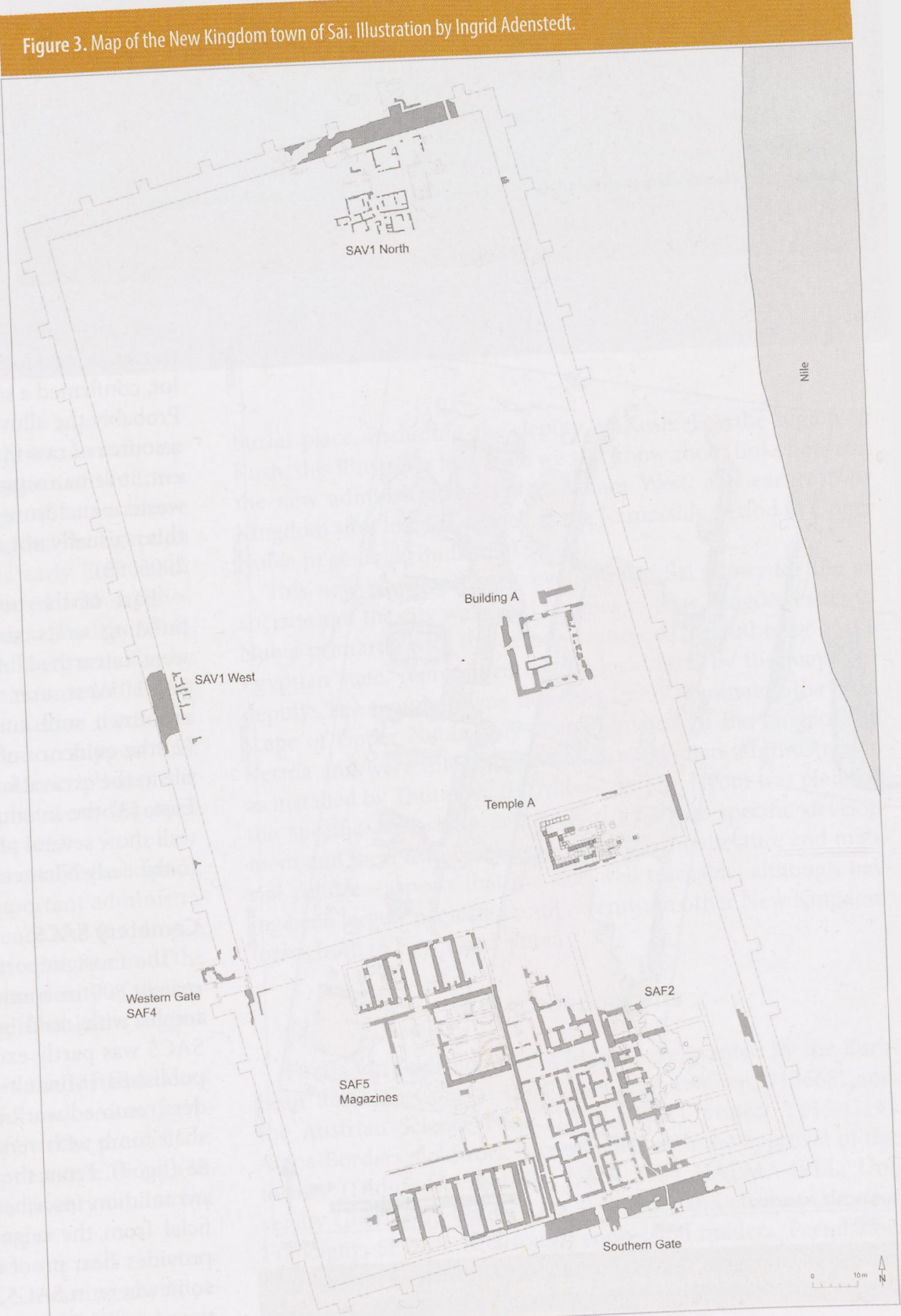




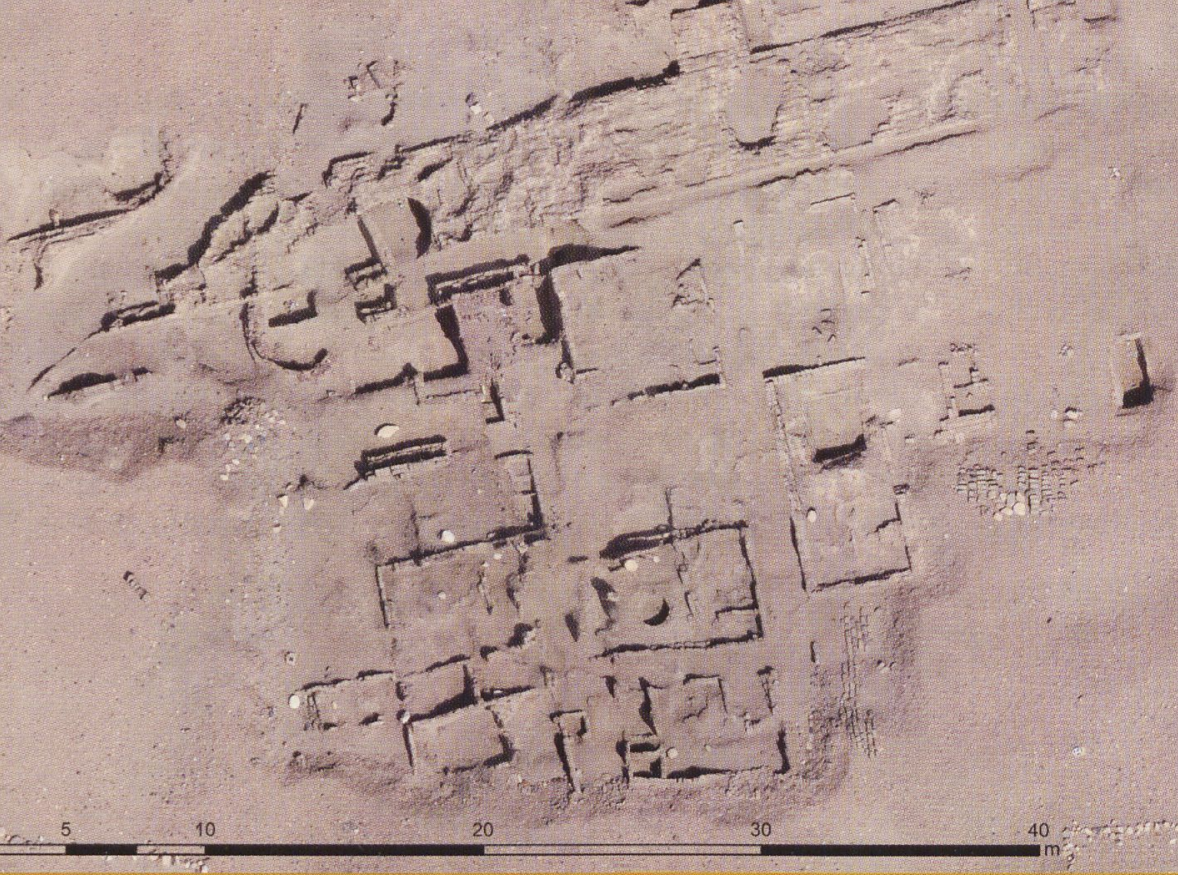

Figure 4. Orthophoto of sector SAV1 North. Photo by Martin Fera.
Building A and Temple A, probably characteristic for a New Kingdom temple town.

\section{Sector SAV1 West}

In 2014, the new site SAV1 West was opened in line with the western town gate in order to search for the town enclosure, its date, structure, and stratigraphic position (Budka 2015b: 63-65). Both the New Kingdom town enclosure and the contemporaneous remains on the inner side of this wall were investigated (fig. 6). Despite much ancient destruction, the complete thickness of the town wall is now visible $(4.3-4.5 \mathrm{~m})$ and in some parts the foundation level has been reached. The alignment of the enclosure wall follows exactly the plan as assumed by previous surveying (Azim 1975: 94, pl. II, 120-22).

West of the newly exposed section of the western town wall, a ditch was observed, similar to what Azim found at the main city gate (Azim 1975: 121-22). A sequence of augering transects, conducted in 2016 by Sayantani Neogi and Sean Taylor, confirmed a sand-filled depression of at least $3.4 \mathrm{~m}$ in depth. Probably the alluvium extracted to create this ditch was used as a source of raw material for the mud bricks of the town. At present, it remains unclear whether this deep ditch in front of the western enclosure of Sai also had a defensive character, because this is usually not attested for temple towns in Nubia (see Morris 2005: 98).

East of the town enclosure at SAV1 West, several small building units similar to the ones in sector SAV1 North were unearthed. All in all, the most significant results from SAV1 West are: (1) the confirmed position of the western town wall and its foundation date under Thutmose III; (2) the evidence of early Eighteenth Dynasty activity comparable to the excavation results from sectors SAV1 North and SAV1 East; (3) the in situ New Kingdom structures east of the town wall show several phases and spanning from the mid-Eighteenth to the early Nineteenth Dynasty.

\section{Cemetery SAC5}

The most important Egyptian cemetery on Sai lies approximately $800 \mathrm{~m}$ south of the town and contains Pharaonic-style tombs with mud-brick chapels and pyramid superstructures. SAC5 was partly excavated by the French mission and recently published (Minault-Gout and Thill 2012). In 2015, AcrossBorders resumed work in SAC5 (Budka 2015d), discovering a new shaft tomb with very scarce remains of a superstructure, Tomb 26 (fig. 7). From the shaft fill, the most important object was a pyramidion inscribed for the deputy of Kush Hornakht, an official from the reign of Ramesses II (fig. 8). The pyramidion provides clear proof that the highest official of Kush was buried somewhere in SAC5, if not in Tomb 26 itself. This evidence for the use of SAC 5 by high-ranking officials of the early Nineteenth 
Dynasty Egyptian administration is of great importance because it is well established that Amara West was the administrative center of Kush from the reign of Seti I until the end of the New Kingdom.

\section{Reflections of the Urban Landscape of New Kingdom Kush in the Archaeology of Sai Island}

AcrossBorders' fieldwork in both the town and the cemetery allows the reconstruction of three main phases for the evolution of New Kingdom Sai. These phases seem to reflect general settlement patterns for the region of Kush, which need to be explored further (Budka 2015c).

Phase A: In the early Eighteenth Dynasty, Sai was probably little more than a simple landing place and supply base for the Egyptians during the reigns of Ahmose Nebpehtyra, Amenhotep I, and Thutmose I. The size and internal structure of the town at this early stage remains unclear and no sign of an enclosure wall was found. The evidence from Sai suggests that the Egyptian sites were largely dependent on Egypt in the early Eighteenth Dynasty - the region was centrally administered and supplies were brought from Egypt, including ceramics (Budka 2016). Despite the Egyptian presence and attested military activities by Ahmose and others, no major permanent Pharaonic settlement sites were built during this phase in former Kerma territories like Sai. Recent excavations at Dukki Gel seem to support this: the mnnws (fortified towns known from royal inscriptions) that Thutmose I built there did not last very long, but were destroyed during the Kerma revolt (see Budka 2015a: 64-65).

Phase B: The walled settlement on Sai was established during the time of Thutmose III and became an important administrative center with a temple, a governor's residence and Building A as a substantial administrative building. The enlargement of the site goes hand in hand with an increasing complexity of the material culture, and varied lifestyles among the inhabitants suggest a complex social stratification.

For the region of Kush, Phase B mirrors the installation of a permanent Egyptian administration. At all major sites, Egyptian architecture and material culture testify to the presence of Egyptians and to the appropriation of Egyptian style though in digenous elements, resulting in a lifestyle that is very similar, but not completely identical to sites in Egypt proper.

Phase C: New finds from both the town site and cemetery SAC5 stress the continued importance of Sai during the Nine teenth Dynasty. The island was still used by high officials as a burial place, including the deputy of Kush. For the region of Kush, this illustrates how little we still know about links between the new administrative center, Amara West, and earlier New Kingdom sites like Sai, as well as the Ramesside period in Upper Nubia in general (Budka 2015c: 48).

This new phasing for the evolution of Sai allows for the association of the city walls and temples in New Kingdom sites in Nubia primarily with the demonstration of the authority of the Egyptian state, represented on the local level by the mayor or deputy. The temple towns flourished and dominated the landscape of Upper Nubia only after the defeat of the kingdom of Kerma and were integral parts of the Egyptian administration as installed by Thutmose III. Although their layout was planned, the specific sites show evidence of local site-specific development and local features in regard to both architecture and material culture-aspects that are also well traceable, although having been largely neglected until recently, in other New Kingdom towns both in Egypt and Nubia.

\section{Acknowledgments}

Funds for fieldwork on Sai Island were granted by the European Research Council (ERC Starting Grant no. 313668) and the Austrian Science Fund (FWF START project Y615-G19). AcrossBorders' fieldwork is conducted with the approval of the former (Didier Devauchelle; UMR 8164 HALMA-IPEL, University Charles-de-Gaulle Lille 3, France) and current (Vincent Francigny; SFDAS, Khartoum) concession holders. Permission to work in the field is kindly granted by the National Corporation for Antiquities and Museums of Sudan (NCAM) and sincere 


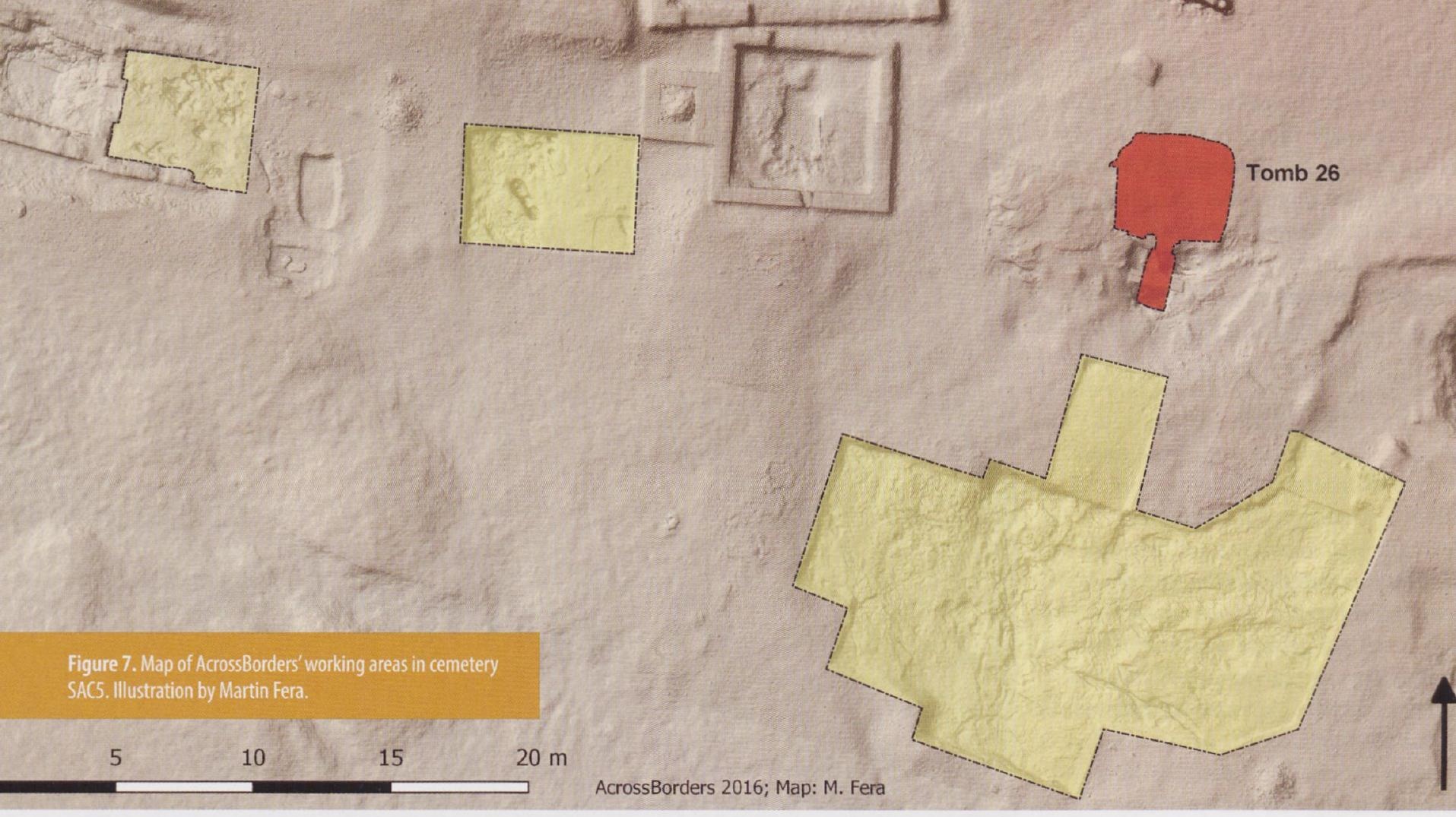

Figure 7. Map of AcrossBorders' working areas in cemetery Sic 5. Illustration by Martin Fera.

$\begin{array}{llll}5 & 10 & 15 & 20 \mathrm{~m}\end{array}$
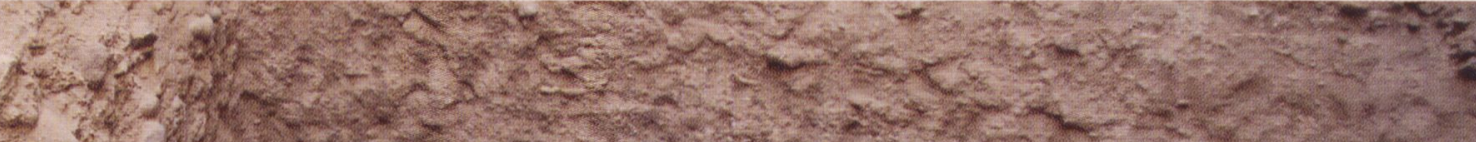

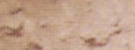
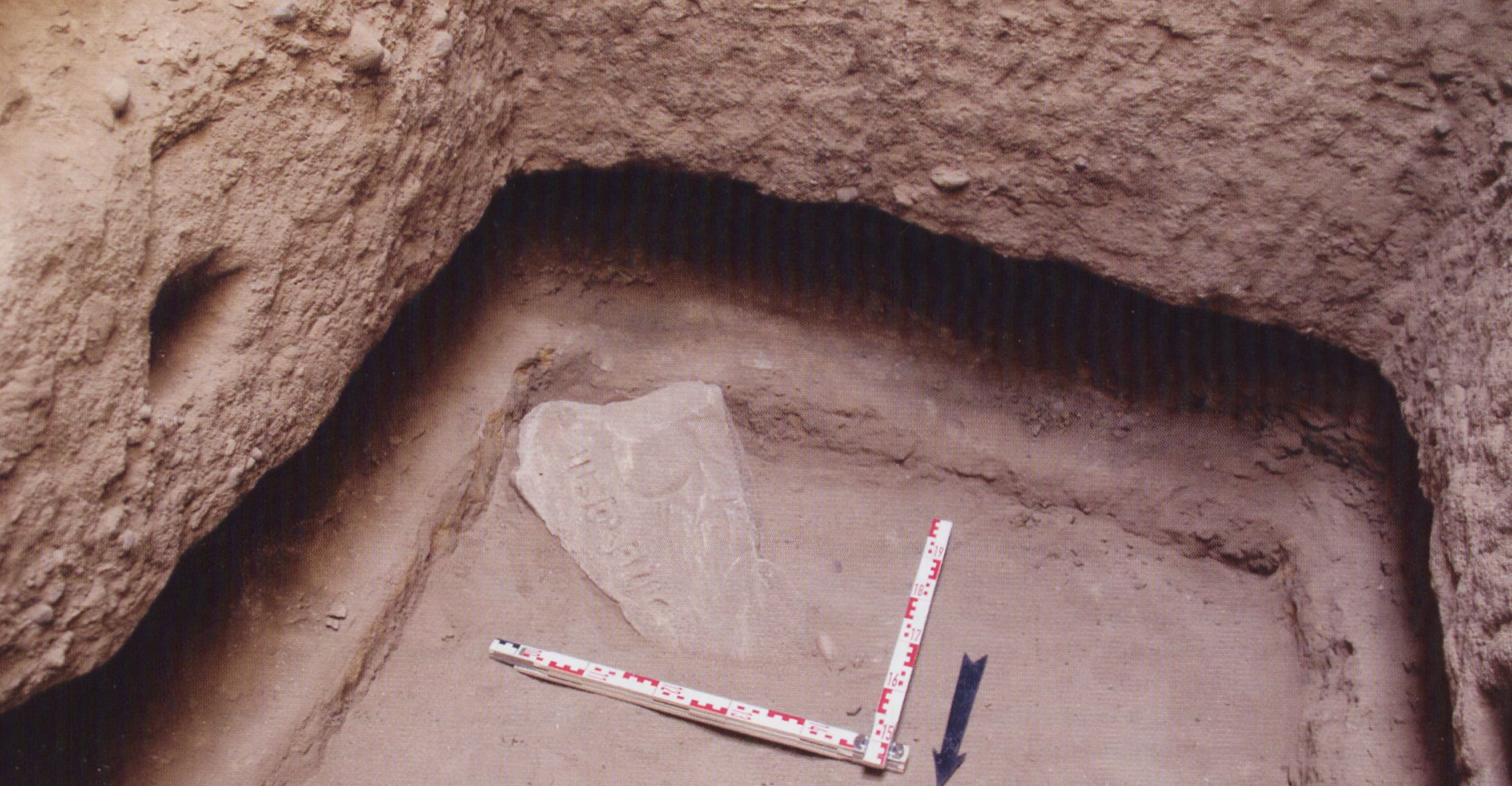
thanks go in particular to Abdelrahman Ali Mohamed (Director General), El-Hassan Ahmed Mohamed (Director of Fieldwork), and Huda Magzoub (NCAM inspector). The written English of this paper was graciously improved by Meg Gundlach.

\section{References}

Adenstedt, Ingrid. 2016. Reconstructing Pharaonic Architecture in Nubia: The Case Study of SAV1, Sai Island. Vienna: Austrian Academy of Sciences Press.

Azim, Michel. 1975. Quatre campagnes de fouilles sur la Forteresse de Saï, 1970-1973. $1^{\text {ère }}$ partie: l'installation pharaonique. Cahiers de Recherches de l'Institut de Papyrologie et d'Égyptologie de Lille 3: 91-125.

Budka, Julia. 2015a. The Egyptian "Re-conquest of Nubia” in the New Kingdom: Some Thoughts on the Legitimization of Pharaonic Power in the South. Pp. 63-82 in Royal versus Divine Authrority: Acquisition, Legitimization and Renewal of Power, ed. Filip Coppens, Jiri Janák, and Hana Vymazalová. Wiesbaden: Harrassowitz.

2015b. The New Kingdom in Nubia: New Results from Current Excavations on Sai Island. Egitto e Vicino Oriente 37: 55-87.

2015c. The Pharaonic Town on Sai Island and Its Role in the Urban Landscape of New Kingdom Kush. Sudan \& Nubia 19: 40-53.

2015d. Ein Pyramidenfriedhof auf der Insel Sai. Sokar 31: 54-65.

2017. Life in the New Kingdom Town of Sai Island: Some New Perspectives. Pp. 429-47 in Nubia in the New Kingdom: Lived Experience, Pharaonic Control and Indigenous Traditions, ed. Neal Spencer, Anna Stevens, and Michaela Binder. Leuven: Peeters.

Budka, Julia, and Florence Doyen. 2013. Living in New Kingdom Towns in Upper Nubia: New Evidence from Recent Excavations on Sai Island. Egypt \& the Levant 22/23: 167-208.

Davies, W. Vivian. 2005. Egypt and Nubia: Conflict with the Kingdom of Kush. Pp. 49-56 in Hatshepsut: From Queen to Pharaoh, ed. Catherine H. Roehrig. New York: Metropolitan Museum of Arts.

Geus, Francis. 2004. Sai. Pp. 114-16 in Sudan. Ancient Treasures: An Exhibition of Recent Discoveries from the Sudan National Museum, ed. Derek A. Welsby and Julie R. Anderson. London: British Museum Press.

Gratien, Brigitte. 1986. Saï I: la nécropole Kerma. Paris: CNRS.
Hafsaas-Tsakos, Henriette, and Alexandros Tsakos. 2012. A Second Look into the Medieval Period on Sai Island. Beiträge zur Sudanforschung 11: 75-91.

Kemp, Barry J. 1972. Fortified Towns in Nubia. Pp. 651-56 in Man, Settlement and Urbanism, ed. Peter J. Ucko, Ruth Tringham, and G. W. Dimbleby. London: Duckworth.

Klemm, Rosemarie, and Dieter Klemm. 2013. Gold and Gold Mining in Ancient Egypt and Nubia: Geoarchaeology of the Ancient Gold Mining Sites in the Egyptian and Sudanese Eastern Deserts. New York: Springer.

Minault-Gout, Ann, and Florence Thill. 2012. Saï II: le cimetière des tombes hypogées du Nouvel Empire (SAC5). Cairo: Institut français d'archéologie orientale du Caire.

Morris, Ellen F. 2005. The Architecture of Imperialism: Military Bases and the Evolution of Foreign Policy in Egypt's New Kingdom. Leiden: Brill.

Müller, Ingeborg. 2013. Die Verwaltung Nubiens im Neuen Reich. Wiesbaden: Harrassowitz.

Pelt, W. Paul van. 2013. Revising Egypto-Nubian Relations in New Kingdom Lower Nubia: From Egyptianization to Cultural Entanglement. Cambridge Archaeological Journal 23: 523-50.

Spataro, Michaela; Marie Millet; and Neal Spencer. 2015. The New Kingdom Settlement of Amara West (Nubia, Sudan): Mineralogical and Chemical Investigation of the Ceramics. Archaeological and Anthropological Sciences 7: 399-421.

Spence, Kate, and Pamela J. Rose. 2009. Fieldwork at Sesebi, 2009. Sudan \& Nubia 13: 38-46.

Spence, Kate, Pamela J. Rose et al. 2011. Sesebi 2011. Sudan \& Nubia 15: 34-39.

Spencer, Neal. 2014a. Creating a Neighborhood within a Changing Town: Household and Other Agencies at Amara West in $\mathrm{Nu}$ bia. Pp. 169-210 in Household Studies in Complex Societies: (Micro) Archaeological and Textual Approaches, ed. Miriam Müller. Chicago: The Oriental Institute of the University of Chicago.

2014b. Creating and Re-shaping Egypt in Kush: Responses at Amara West. Journal of Ancient Egyptian Interconnections 6: $42-61$.

Spencer, Neal; Mark Macklin; and Jamie Woodward. 2012. Re-assessing the Abandonment of Amara West: The Impact of a Changing Nile? Sudan \& Nubia 16: 37-47.

Woodward, Jamie et al. 2015. Shifting Sediment Sources in the World's Longest River: A Strontium Isotope Record for the Holocene Nile. Quaternary Science Reviews 130: 124-40.

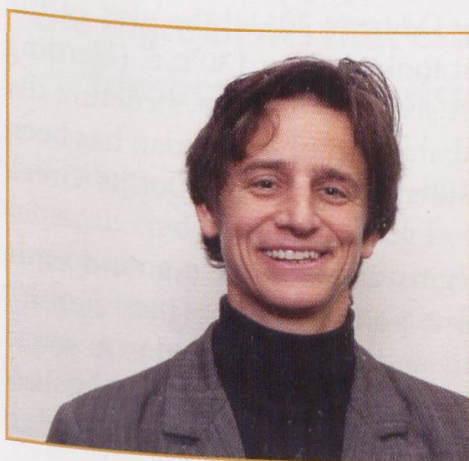

Julia Budka studied Egyptology and classical archaeology at the University of Vienna and received her PhD in Egyptology, University of Vienna in 2007. She held a researcher position at Humboldt University Berlin (2004-2012) and was a temporary replacement assistant professor at the University of Vienna (2011-2012). With a START Prize (2012) and ERC starting grant (2012), she implemented her project AcrossBorders at the Austrian Academy of Sciences. Since 2015, Julia Budka has been professor in Egyptian archaeology and art at the Ludwig Maximilian University of Munich. 